Open Access

\title{
The influences of leaders' dark triad trait on their perception of CSR
}

\author{
Jae Kyu Myung ${ }^{*}$ (D) and Yun Hyeok Choi
}

\author{
* Correspondence: \\ gilmyung@gmail.com \\ Inha University, Bldg.\#6-306, 100 \\ Inha-ro, Nam-gu, Incheon 22212, \\ South Korea
}

\begin{abstract}
The dark triad is a psychological term explaining individual negative dispositions. It is composed of Machiavellianism, which is a tendency to manipulate others to gain advantage, psychopathy, which is a general lack of empathy, and narcissism, which is excessive self-love. The negative effects of any leader's unethical behaviors on society necessitate an examination of the relationship between the leader's undesirable propensity and the corporate social responsibility (CSR). The literature reveals that the characteristics and traits of an organization's leader affect the ethics of the organization and that the leader's ethical perception and judgment can affect CSR. Accordingly, it is critical for a leader with the dark triad trait to check his or her perception of CSR. In addition, it is necessary to determine how the individual performance-based compensation system moderates the relationship between a leader's dark triad trait and CSR perception. Although a compensation system is useful in enhancing performance, it can have negative effects due to excessive and exclusive emphasis on performance. Empirical results have shown that Machiavellianism and psychopathy negatively affect the perception of CSR as a prima facie duty. Especially in this relation, the individual performance-based compensation system improves the negative relationship between Machiavellianism and CSR perception, and exacerbates the negative relationship between psychopathy and CSR perception. However, the psychopathy trait has only a negative relationship with the perception of CSR as a top priority, and the other traits have no significant relationship with the perception of CSR as a top priority. The study conclusions are summarized as follows: 1) the leader's perception of CSR is affected by his or her negative traits like Machiavellianism and psychopathy, 2) an organization needs to investigate the performance evaluation system and indicators for avoiding a negative influence of the system, and 3) it is necessary to find effective and practical managerial approaches capable of controlling the potential negative traits desirably.

Keywords: Compensation system, CSR, Dark triad, Machiavellianism, Narcissism, Psychopathy
\end{abstract}

\section{Introduction}

Since the end of the 1990s, considerable attention and research have been focused on the field of CSR worldwide. As the corporate influence on society grows, social demands are increasing for company to introduce CSR and instigate related activities. Now, CSR is focused on as a strategic management issue. Accordingly, more companies have introduced CSR to their management. In Korea, interest in and academic research on corporate sustainability and CSR have increased since 2000.

(c) The Author(s). 2017 Open Access This article is distributed under the terms of the Creative Commons Attribution 4.0 International License (http://creativecommons.org/licenses/by/4.0/), which permits unrestricted use, distribution, and reproduction in any medium, provided you give appropriate credit to the original author(s) and the source, provide a link to the Creative Commons license, and indicate if changes were made. 
Most discussions on the original concept of CSR suggested by Bowen (1953) focused on whether a company's manager should take ethical responsibility for the social demand, i.e., whether an organization's CSR activities vary depending on the organizational leader's perception on ethics and social responsibility (Skouloudis and Evangelinos 2012). As a responsible leader is a major element in determining the relation with the organization and the stakeholders (Waldman and Galvin 2008) and since the leader's personality and values determine the perception of CSR, the leader is very critical in introducing, keeping and development CSR (Quazi 2003). Likewise, Waldman et al. (2006) also argued that the ethical leaders positively affect CSR.

Nevertheless, no attention has been directed at the relationship between the unethical traits of the company's leader and his or her perception of social responsibility. Moreover, media reports of company managers' delinquencies raise interest in the relationship between a leader's negative trait and the perception of CSR. In South Korea, the mass media widely covered big news stories about Namyang Dairy Product Co., Ltd. ${ }^{1}$, Korean Air, ${ }^{2}$ POSCO Energy ${ }^{3}$, Samsung semiconductor factory ${ }^{4}$, and the Scandal ${ }^{5}$ between President and Chaebols since 2010. These stories were related to ethical, social and leadership issues, and highlighted a need to consider the relationship. In this study, the dark triad (Machiavellianism, psychopathy and narcissism) was used as the representative negative trait. Those with this trait tend to deal with others unethically or manipulatively (Furtner et al. 2011). Other studies, however, have reported that their superficial attractions such as cool-headed or cold-blooded behavior help them to climb the corporate ladder (Babiak et al. 2010). Therefore, it is necessary to identify the relationship between the dark triad of an organization's leader and his or her perception of ethics and social responsibility.

Lastly, we have investigated whether the individual performance-based compensation system played any moderating role between the dark triad of an organization's leader and his or her perception of CSR. The human resource management system has experienced major changes in South Korea since the financial crisis of 1997. It is well known that, the individual performance-based compensation systems have been widely adopted in every aspect to firms, according to global standards (Yu and Park 2007). Bae and Park (2005) articulated that Korean firm has focused on short-term performance allowed the firm to set its goals. Therefore, the individual performance-based compensation has weakness in Korean context, although designed to be beneficial to all, owing to focusing on the achievement of business outputs. The system, thus, can lead to unethical behaviors at the expense of other value when a leader who has negative propensity exists in an organization. Therefore, it is necessary to determine whether the individual performance-based compensation system moderates the relationship between the dark triad trait and the perception of CSR.

\section{Dark triad trait}

Kowalski (2001) regarded Machiavellianism, psychopathy and narcissism as social-aversive personality traits. Paulhus and Williams (2002) deemed them to be socially undesirable as an aggressive personality and termed them the 'Dark Triad' with a negative personality trait primarily. Machiavellianism has some characteristic ways of deceitful behaviors, wickedness, cunningness, and hypocrisy (Corral and Calvete 2000). According to Geis and 
Moon (1981), Machiavellianism traits are self-beneficial behaviors, lack of empathy, deception and interpersonal manipulation (Jakobwitz and Egan 2006; Furtner et al. 2011). Those with a Machiavellianism trait attempt to gain advantage by any means necessary, with no consideration for ethics. Additionally, Machiavellianism suppresses other's feeling in order to establish and attain one's own purpose, emphasizes practicability, and has the strong desire for harsh power (Ali et al. 2009). Machiavellian leaders tend to ignore ethical issues without prudence and with no attempt to solve them (Ford and Richardson 1994). Machiavellianism has a negative relationship with the perception of business ethics (Simmons et al. 2009).

Psychopathy is divided into primary psychopathy (e.g., selfishness, deficiencies in interpersonal affect, remorselessness, superficial charm, exploitation) and secondary psychopathy (antisocial lifestyle and behaviors) (Karpman 1948). As argued later, Machiavellianism and primary psychopathy are essentially identical constructs (McHoskey et al. 1998). Nathanson et al. (2004) presented manipulation, a lack of affective experiences, and impulsive or irresponsible behavior as characteristics of psychopathy. It can be rendered as glibness and superficial charm, manipulation, cunning, coldness, grandiose sense of self-worth, lack of remorse and empathy, emotionally shallow, calculating, and refusing to take responsibility for their own actions (Boddy et al. 2010; Williams et al. 2002). Boddy (2011) mentioned that the global financial crisis in 2008 proceeded from the psychopaths who worked in firms and financial service providers.

The narcissism trait induces a strong desire to achieve recognition of one's superiority and, in order to prove it, attempts to gain attention and envy. Narcissistic supply appears out of compliment, affirmation and flattery, which are identified by others (Wallace and Baumeister 2002; Chatterjee and Hambrick 2007). The narcissism trait attempts to attain others' envy by means of fulfilling a hard or challenging mission voluntarily. Cognitively, the narcissism trait is presented in any constant personal differences (self-love, selfassessment, exaggeration, grandiosity) compared with others (Morf and Rhodewalt 2001; Campbell et al. 2006), such as in exaggerating, oppressive, egocentric and dominant personalities (Emmons 1987; Sedikides et al. 2002). Narcissists tend to overvalue their creativity, leadership, ability and intelligence compared with all others (Robins and John 1994; Farwell and Wohlwend-Lloyd 1998; Judge et al. 2006).

\section{Theoretical background and hypothesis development Leaders' dark triad trait and their CSR perception}

The attitude of leaders is a salient component in establishing positive relationships with a variety of stakeholders (Waldman and Galvin 2008). Furthermore, the personality of the leader of an organization like a CEO is an important driver in deciding the perception of social responsibility, and his or her morality positively affects CSR (Quazi 2003; Waldman et al. 2006).

CSR is understood as a discretionary and strategic management (William and David 2011), and thus varies according to each company's unique situation (Marrewijk and Werre 2003; Peng 2008). The strategic CSR is in the area of a leader's personal decision-making (Robbins 2008; Thomas and Simerly 1994), and virtue of the leader's authority (Batra 2007). The CEO's trait has been dealt with as an important factor of organizational behaviors (Klann 2003). Therefore, a leader's ethical attitude is a critical point in determining the level of CSR which is performed discretionarily. 
The dark triad has several common characteristics: callous, twofold, self-interested and exploitative personality. A leader with the dark triad trait may manipulate, exploit and deceive colleagues, and conduct morally inappropriate behavior while avoiding cooperation and collective solution with co-workers (Furtner et al. 2011). An ethical culture in an organization is an important element in a positive perception of CSR, and a leader's undesirable traits are related with individual attitudes in an organizational culture (Valentine and Fleischman 2008). Machiavellianism has a negative relationship with business ethics (Simmons et al. 2009). Similarly, a lack of empathy, which is a representative disposition of psychopathy, may negatively affect a company. Therefore, the probability that narcissism does not enrich the substance of CSR owing to regarding social responsibility as a superficial means to prove oneself and gratify self-attachment is presumed to be high. Narcissistic leaders aggrandize their power with self-conviction, although they may make irresponsible judgements and decisions (Hogan et al. 1990).

In other words, the stronger a leader's dark triad trait in an organization, the more unethical management practices increase, and the higher others' stress (Fox 2000). Therefore, it can be anticipated that the dark triad is coupled with the level of perception of and concern for CSR negatively. The ethics of top managements works as an essential driver of a responsible corporate citizen's activities (Perrini 2006; Swanson 2006; Valentine and Fleischman 2008). The dark triad may not recognize CSR as a critical issue and may have little attention to solve social and environmental problems (Singhapakdi and Vitell 1991).

Because personal values, dispositions and characteristics determine the CSR perception (Quazi 2003), the leader as a decision-maker plays an important part in the initialization, maintenance and development of CSR. Therefore, it can be anticipated that the dark triad will result in forming a usual practice of ignoring ethics and social responsibility, and influence the level of CSR perception. Based on the above discussion, the following hypothesis can be proposed:

Hypothesis 1. The dark triad traits (Machiavellianism, psychopathy and narcissism) of a leader in an organization are negatively related to his or her perception of CSR.

\section{The moderating effect of the individual performance-based compensation system}

The individual performance-based compensation system is a market-based system which focuses on results of employees' tasks. It therefore must be developed and operated strategically in terms of human resource management. Especially, this system is an individual management system that is connected with organization goals, individual performance and team achievements, and that differentiates rewards. In terms of conventional organizational behavior, the offering of clear rewards to the related achievements can be a strong motivation (Heneman 1992; Milkovich and Newman 1996; Yu and Park 2007).

However, the motivation effect of individual performance-based compensation system is not always positive. If only exogenous reward with regard to task outputs is offered, the self-determination of a management implementer tends to be decreased, and intrinsic job-motivation will be further decreased accordance with developing an attention for rewards (Deci 1971; Eisenberger and Armeli 1997; Collins and Amabile 1999). Similarly, when the polarization of the compensation level becomes more serious, employees may lack their self-efficacy and job satisfaction, and thus lose self-respect and intrinsic motivation (Heneman 1992; Deci et al. 1999). 
In accordance with the goal-oriented or egocentric disposition of dark triad traits, an individual performance-based compensation system can stimulate the disposition. Nearly one-third of financial services professionals reported that their bonus or compensation plans created pressure to engage in unethical or illegal behavior, according to the New York Times ${ }^{6}$. Because the dark triad trait tends to neglect cooperation and communications with others, a leader with the trait will manipulate others much more and give little attention to ethics or CSR in order to maximize his or her profits.

Bazerman and Tenbrunsel (2011) articulated that compensation systems are usually designed with good intentions, but it is a possibility that their goals will not be achieved, because no one can predict accurately how employees will respond to the rewards system. The performance-based compensation system of Korean companies has concentrated on the typical business performance (Park 2007), thus, the desirable perception of ethics or social responsibility which is excluded from the reward system is suppressed (Bazerman and Tenbrunsel 2011). Moreover, supposed to the dark triad traits of self-beneficial behavior and lack of empathy, the compensation system can be expected to exacerbate the perception of CSR, and consider visible outputs more importantly. Therefore, the CSR that is connected with not direct and short-term results but long-term value may be dealt with unimportantly. As mentioned above, the following hypothesis on the individual performance-based compensation system can be made:

Hypothesis 2. The individual performance-based compensation system moderates the relationship between the dark triad trait of a leader and his or her perception of CSR

\section{Research methods}

\section{Sample}

In order to conduct an efficient survey process, an online survey method was employed, and the questionnaire was completed using the online methodology of the KSDC (Korea Social Science Data Center ${ }^{7}$ ) was utilized. The questionnaires were sent to the person in charge of each company by e-mail, and were completed on-line. The demographic variables like gender, age, educational background, service period of employee, position level in an office and task assignment were taken into account to remove any response bias, and then the survey was conducted after calling every respondent. The analysis of unit of this study was the individual level, however, as great a variety of companies as possible was included.

The survey was conducted in April and May 2014. Total 207 valid responses were received. All responses were checked to avoid duplication by telephone, e-mail and IP address of respondents. In the sample, $83.09 \%$ of respondents (172) were men, $57.01 \%$ (118) had been working for more than 5 years, 92.27\% (191) had graduate or post-graduate degrees, and everyone, from directors to assistant manager, were evenly participated in the survey. The industries, the task assignments and the position levels in an office included in the sample are tabulated in Table 1. These data were utilized as a control variable.

\section{Measurements}

The individual items of the questionnaire were derived from several established scales in preceding studies after being translated into Korean from the original English. The Dirty Dozen scale (Jonason and Webster 2010) was used for the dark triad trait of a 
Table 1 Demographic variables

\begin{tabular}{|c|c|c|c|c|c|c|c|c|}
\hline Industries & Portion & $\begin{array}{l}\text { Sample } \\
\text { size }\end{array}$ & Task assignments & Portion & $\begin{array}{l}\text { Sample } \\
\text { size }\end{array}$ & $\begin{array}{l}\text { Position levels } \\
\text { in an office }\end{array}$ & Portion & $\begin{array}{l}\text { Sample } \\
\text { size }\end{array}$ \\
\hline $\begin{array}{l}\text { Petrochemical } \\
\text { industry }\end{array}$ & $9.7 \%$ & 20 & HR/labor & $4.8 \%$ & 10 & $\begin{array}{l}\text { Above } \\
\text { directors }\end{array}$ & $11.6 \%$ & 24 \\
\hline $\begin{array}{l}\text { Metal and minerals } \\
\text { production }\end{array}$ & $3.9 \%$ & 8 & $\begin{array}{l}\text { Furnace and } \\
\text { accounting }\end{array}$ & $6.8 \%$ & 14 & Managers & $44.5 \%$ & 92 \\
\hline $\begin{array}{l}\text { Electronic } \\
\text { manufacturing }\end{array}$ & $9.2 \%$ & 19 & $\begin{array}{l}\text { Planning and } \\
\text { strategy }\end{array}$ & $10.6 \%$ & 22 & $\begin{array}{l}\text { Assistant } \\
\text { managers }\end{array}$ & $43.9 \%$ & 91 \\
\hline $\begin{array}{l}\text { Vehicle } \\
\text { manufacturing }\end{array}$ & $5.8 \%$ & 12 & $R \& D$ & $10.1 \%$ & 21 & & & \\
\hline $\begin{array}{l}\text { Food and beverage } \\
\text { manufacturing }\end{array}$ & $3.4 \%$ & 7 & $\begin{array}{l}\text { Marketing and } \\
\text { sales }\end{array}$ & $35.7 \%$ & 74 & & & \\
\hline $\begin{array}{l}\text { Information and } \\
\text { telecommunication } \\
\text { industry }\end{array}$ & $9.7 \%$ & 20 & $\begin{array}{l}\text { Production and } \\
\text { procurement }\end{array}$ & $3.9 \%$ & 8 & & & \\
\hline Other manufacturing & $4.8 \%$ & 10 & $\begin{array}{l}\text { Management } \\
\text { supports }\end{array}$ & $20.3 \%$ & 42 & & & \\
\hline $\begin{array}{l}\text { Construction and } \\
\text { real estate }\end{array}$ & $7.2 \%$ & 15 & $\begin{array}{l}\text { Audit, evaluation } \\
\text { and consulting }\end{array}$ & $7.7 \%$ & 16 & & & \\
\hline $\begin{array}{l}\text { Retail and distribution } \\
\text { industry }\end{array}$ & $7.2 \%$ & 15 & & & & & & \\
\hline $\begin{array}{l}\text { Financial and banking } \\
\text { business }\end{array}$ & $20.8 \%$ & 43 & & & & & & \\
\hline Public services & $3.4 \%$ & 7 & & & & & & \\
\hline Other services & $15.0 \%$ & 31 & & & & & & \\
\hline Total & $100 \%$ & 207 & Total & $100 \%$ & 207 & Total & $100 \%$ & 207 \\
\hline
\end{tabular}

leader as the independent variable. This scale is composed of 12 items with four items each used to identify Machiavellianism, psychopathy and narcissism. Among the various scales (Raskin and Hall 1981; Levenson et al. 1995; Lee and Ashton 2005; Ames et al. 2006; Paulhus et al. 2006) for the dark triad, the Dirty Dozen scale is the simplest scale, and therefore is appropriate for this study which has a number of other items. The response is from 1 to 6 for each item (from 1 not at all to 6 very much). The leader's perception of CSR was estimated with the Perceived Role of Ethics and SOcial Responsibility (PRESOR) developed by Singhapakdi et al. (1996). This scale has been widely used as a measurement method for manager's perception of ethics and social responsibility (Etheredge 1999; Vitell, and Paolillo 2004; Promislo et al. 2012). The same 6-point scale was used as in the Dirty Dozen scale. Higher scores also indicated that the respondents felt that they placed greater importance on ethics and social responsibility.

For the moderator, the individual performance-based compensation system, this paper utilized the measurement method used by Kim and Kim (2006). This scale consists of seven items that deal with annual payments, performance-based incentives, and substantial salary gap etc. The respondents checked a score of 0 (no) or 1 (yes). Owing to the dichotomous scoring method, Therefore, the maximum score was seven and the minimum score was zero. All the items of these variables are in Table 2.

The common method bias was controlled. The dependent variables and the independent variables were conducted through the survey, and therefore all of the questionnaires were rearranged in order to prevent respondents from interpreting the meaning of questionnaires differently (Converse and Presser 1986; Park et al. 2007). Social desirability 
Table 2 Scales

\section{Dirty dozen scale}

1. I tend to manipulate others to get my way.

2. I have used deceit or lied to get my way.

3. I have used flattery to get my way.

4. I tend to exploit others towards my own end.

5. I tend to lack remorse.

6. I tend to be unconcerned with the morality of my actions.

7. I tend to be callous or insensitive.

8. I tend to be cynical.

9. I tend to want others to admire me.

10. I tend to want others to pay attention to me.

11. I tend to seek prestige or status.

12. I tend to expect special favors from others.

$1 \sim 4$ : Machiavellianism

$5 \sim 8$ : Psychopathy

$9 \sim 12:$ Narcissism

Individual Performance-based Compensation System

1. My company has a practical annual salary system.

2. My company contracts annual salary every year.

3. The basic salary of my company includes the amount of pay which is commensurate with individual abilities such as competence level or skills.

4. My company considers the last annual salary.

5. My company uses the last salary level as a criterion

for current measurement.

6. My company pays a performance-based bonus (merit pays) every year.

7. There is a wage differential within the same job class and seniority in my company.

\section{PRESOR}

1. Being ethical and socially responsible is the most important thing one can do

2. While output quality is essential to corporate success, ethics and social responsibility are not.

3. Communication is more important to the overall effectiveness of an organization than whether or not it is concerned with ethics and social responsibility.

4. Corporate planning and goal setting sessions should include discussions of ethics and social responsibility.

5. The most important concern for a firm is making a profit, even if it means bending or breaking the rules.

6. The ethics and social responsibility of a firm are essential to its long-term profitability.

7. The overall effectiveness of a business can be determined to a great extent by the degree to which it is ethical and socially responsible.

8. To remain competitive in a global environment, business firms will have to disregard ethics and social responsibility.

9. Social responsibility and profitability can be compatible.

10. Business ethics and social responsibility are critical to a company's survival.

11. A firm's first priority should be employee morale.

12. Business has a social responsibility beyond making a profit.

13. If survival of a business enterprise is at stake, then ethics and social responsibility should be ignored.

14. Efficiency is much more important than whether or not it is seen as ethical or socially responsible.

15. Good ethics is often good business.

16. If the stockholders are unhappy, nothing else matters.

was also controlled for, because many survey items included the cognitive aspect. SDS-17 (Stöber 2001) was used. The scale deals not with self-deceptive enhancement, but impression management (Kim et al. 2008), which is fit for applying. SDS-17 was evaluated by dichotomous scoring method giving a score of 0 (no) or 1 (yes). The total score of the items was applied to the analysis. Additionally, six variables were included in the analysis as control variables: three respondent-related variables (gender, service period and position level) and three company-related variables (size, history and industry).

\section{Validity and reliability}

Jonason and Webster (2010), the Dirty Dozen developers, noted that it was possible that Machiavellianism, psychopathy and narcissism may be of each construct or may be dealt with as one of the latent variables. The results of the exploratory factor analysis showed that the 5th indicator was excluded because the communality is lower than .3, and the 1st indicator did not belong to any latent variable. Principal axis factoring and promax rotation were used because it is impossible for social science research to generate zero correlation between the factors.

The KMO and Bartlett test of sphericity were .800 and $p=.000$, respectively, which was statistically acceptable. The result was verified again by exploratory factor analysis 
and confirmatory factor analysis without the $1^{\text {st }}$ and $5^{\text {th }}$ indicators. The results showed that the $2^{\text {nd }}, 3^{\text {rd }}$ and $4^{\text {th }}$ indicators were loaded in the $1^{\text {st }}$ factor (Machiavellianism), the $6^{\text {th }}, 7^{\text {th }}$ and $8^{\text {th }}$ in the $2^{\text {nd }}$ factor (psychopathy), and the $9^{\text {th }}, 10^{\text {th }}, 11^{\text {th }}$ and $12^{\text {th }}$ in the $3^{\text {rd }}$ factor (narcissism). All the results were supported statistically. All the loadings exceeded .5, and Cronbach's $\alpha$ was .784 (Machiavellianism was .657, psychopathy.606, and narcissism.786), which indicated sufficient reliability (internal consistency). The model fit and validity tests were also conducted. The CFI and TLI (incremental fit indices) were .914 and .879 , respectively, and the GFI and the RMSEA (absolute fit indices) were .929 and .082 , respectively. These results demonstrated the good fit of the model to the data. All factor loadings (estimates) exceeded .5 (C.R. > 1.96); therefore, sufficient convergent validity was assumed (Bagozzi and Yi 1988).

For a comprehensive understanding of a leader's perception of CSR, the factor analysis was conducted again. The original PRESOR research (Singhapakdi et al. 1996) offered three factors with 13 indicators, but subsequent studies (Etheredge 1999; Vitell and Paolillo 2004) have reported two factors divided by a reverse-coded item. This factor analysis using the original 16 indicators was performed repeatedly. Principal axis factoring and promax rotation were used. So, two factors appeared and were divided by a reverse question, which is consistent with previous studies. As a result of the factor analysis, the $3^{\text {rd }}, 4^{\text {th }}, 5^{\text {th }}, 11^{\text {th }}, 13^{\text {th }}$ and $14^{\text {th }}$ indicators were excluded because the communality was lower than .3. Consequently, of the reverse-coded indicators, the 2nd, 8 th and 16th were loaded on the first factor and the $1^{\text {st }}, 6^{\text {th }}, 7^{\text {th }}, 10^{\text {th }}$ and $15^{\text {th }}$ were loaded on the second factor. The study named the first factor as a "prima facie duty" and the second factor as a "top-priority" (Vitell and Paolillo 2004).

The KMO and Bartlett test of sphericity were .836 and $p=.000$, respectively, indicating no statistical issue. All the pattern matrix loadings exceeded .3, and Cronbach's $\alpha$ was .828 (top priority: .803; prima facie duty: .739), indicating sufficient reliability. The model fit indices were all acceptable (CFI: .934; TLI: .902; GFI: .928; RMSEA: .095). All factor loadings exceeded .5 (C.R. > 1.96), and AVE values were .421 for top priority and .491 for prima facie duty. Although the AVE values were less than .5 , the construct reliability exceeded .7 (Top Priority: .781; prima facie Duty: .741), which indicates acceptable results. The squared correlation between factors was .442, exceeding the AVE of top priority. However, because all the factors belonged to PRESOR, the results were all acceptable for discriminant validity. The above factor analyses results are summarized in Table 3, and the conceptual model of the paper is shown as Fig. 1.

\section{Results}

\section{Correlations}

To verify the correlations between the variables, Pearson correlation coefficients were evaluated, as shown in Table 4. The relationship between the dependent and independent variables was significant. In particular, Machiavellianism and psychopathy were negatively

Table 3 Factor analysis results

\begin{tabular}{lll}
\hline Latent variables & Dark triad (DT) & Perception of CSR \\
\hline Factor 1 & Machiavellianism & prima facie duty \\
Factor 2 & psychopathy & top priority \\
Factor 3 & narcissism & \\
\hline
\end{tabular}




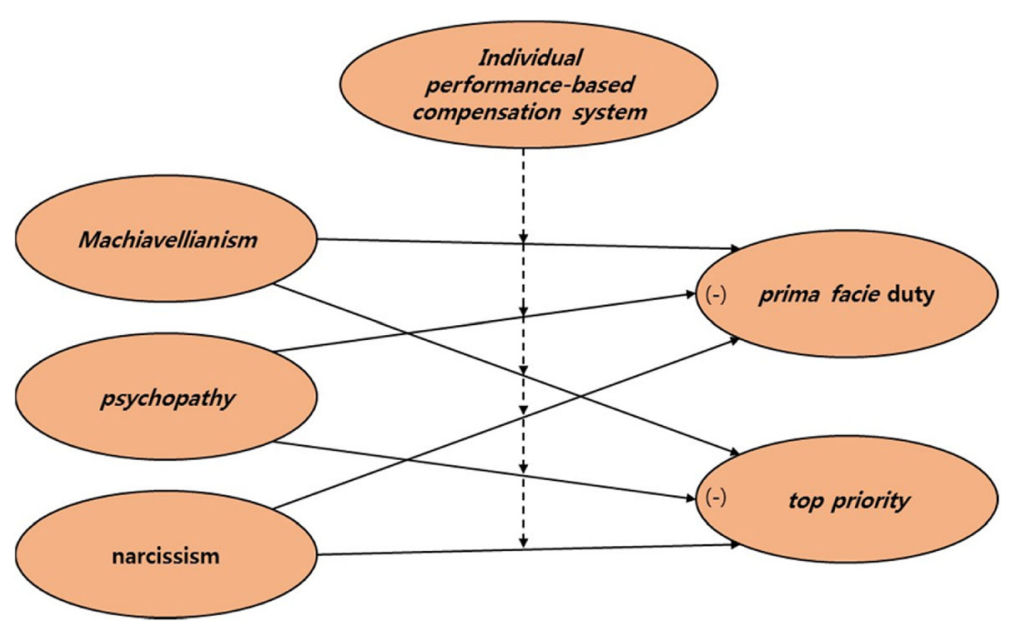

Fig. 1 Research model

correlated with dependent variables, and the moderator, individual performance-based compensation system, was correlated with prima facie Duty and narcissism.

\section{Regression results}

Table 5 shows the hierarchical regression results of the main effect, interaction effect and control effect. Model 1 included control variables, independent variables and moderator, and Model 2 added the interaction variables to Model 1. Regression 1 dealt with the prima facie duty as an independent variable, and Regression 2 analyzed top priority. Six control variables were not significant statistically. The study employed a regression equation instead of a structured equation model due to the variety of control variables. In order to remove multi-collinearity from the moderated regression analysis, meancentering was conducted.

Firstly, three constructs of the independent variable were applied to the regression equation; consequently, Hypothesis 1 was supported partially. The stronger were Machiavellianism and psychopathy traits, the lower was the perception of CSR $(\beta=-.393$, $p<.01 ; \beta=-.368, p<.01$ respectively); however, the narcissism trait had no significant relationship $(\beta=-.093, p>.10)$. In this regression 1 , 'the perception of CSR' means that a

Table 4 Pearson correlations

\begin{tabular}{llllllllll}
\hline Variables & 1. & 2. & 3. & 4. & 5. & 6. & 7. & Mean & S.D. \\
\hline 1. Top priority & 1.000 & & & & & & & 4.39 & .914 \\
2. prima facie Duty & $.681^{* *}$ & 1.000 & & & & & & 4.64 & .898 \\
3. Machiavellianism & $-.294^{* *}$ & $-.513^{* *}$ & 1.000 & & & & & 3.09 & .876 \\
4. Psychopathy & $-.394^{* *}$ & $-.581^{* *}$ & $.691^{* *}$ & 1.000 & & & & 2.73 & .821 \\
5. Narcissism & -0.050 & $-.155^{*}$ & $.652^{* *}$ & $.290^{* *}$ & 1.000 & & 3.84 & .921 \\
$\begin{array}{l}\text { 6. Individual performance-based } \\
\quad \text { compensation Sys. }\end{array}$ & 0.105 & $.176^{*}$ & 0.059 & 0.001 & $.215^{* *}$ & 1.000 & 5.37 & 1.704 \\
7. social desirability & $.246^{* *}$ & $.167^{*}$ & $-.347^{* *}$ & $-.255^{* *}$ & -0.123 & 0.047 & 1.000 & 9.02 & 3.089 \\
\hline
\end{tabular}

**Significant at $p<.01,{ }^{*}$ Significant at $p<.05$ (two-tailed test)

The control variables, except social desirability (gender, service period, position level, size, history and industry), are not included in this table 
Table 5 Regression results

\begin{tabular}{|c|c|c|c|c|c|c|c|c|}
\hline \multirow[t]{3}{*}{ Variables } & \multicolumn{4}{|c|}{$\begin{array}{l}\text { Regression } 1 . \\
\text { (Dependent variable: prima facie duty) } \\
\end{array}$} & \multicolumn{4}{|c|}{$\begin{array}{l}\text { Regression } 2 \\
\text { (Dependent variable: top priority) }\end{array}$} \\
\hline & \multicolumn{2}{|c|}{ Model 1.} & \multicolumn{2}{|c|}{ Model 2.} & \multicolumn{2}{|c|}{ Model 1.} & \multicolumn{2}{|c|}{ Model 2.} \\
\hline & $\beta$ & $t$-value & $\beta$ & $t$-value & $\beta$ & $t$-value & $\beta$ & $t$-value \\
\hline Machiavellianism (Mac) & -.393 & $-3.465^{* * *}$ & -.355 & $-3.100^{* * *}$ & -.154 & -1.134 & -.123 & -.888 \\
\hline Psychopathy (Psy) & -.368 & $-3.871^{* * *}$ & -.411 & $-4.304^{* * *}$ & -.260 & $-2.287^{* *}$ & -.280 & $-2.423^{* *}$ \\
\hline Narcissism (Nar) & .093 & 1.130 & .083 & 1.018 & .083 & 0.849 & .081 & .820 \\
\hline $\begin{array}{l}\text { Individual performance-based } \\
\text { compensation Sys. (IPCS) }\end{array}$ & .076 & $2.392^{* *}$ & .094 & $2.803^{* * *}$ & .042 & 1.114 & .056 & 1.388 \\
\hline Social desirability & -.019 & -1.049 & -.021 & -1.163 & .033 & 1.548 & .034 & 1.545 \\
\hline Mac x IPCS & & & .125 & $1.819^{* *}$ & & & .074 & .887 \\
\hline Psy $\times$ IPCS & & & -.137 & $-2.590^{* *}$ & & & -.050 & -.777 \\
\hline Nar x IPCS & & & -.043 & -.842 & & & -.012 & -.195 \\
\hline$R^{2}$ & & .507 & & .527 & & .321 & & .327 \\
\hline F-value & & & & $4.918^{* * *}$ & & & & $2.153^{* * *}$ \\
\hline
\end{tabular}

***Significant at $p<.01,{ }^{* *}$ Significant at $p<.05,{ }^{*}$ Significant at $p<.10$ (two-tailed test)

The control variables except social desirability (gender, service period, position level, size, history and industry) were not included in this table

leader perceives CSR as a prima facie duty; therefore, it is nothing to do with the important perception of CSR. Even though the level of prima facie duty is higher, CSR perception will not transform to CSR perception as a top priority.

When the Machiavellianism trait, which is an extreme results-oriented propensity to achieve success by any means, is strong, the obligatory perception level of CSR will be low. When the psychopathy trait, which is a lack of empathy and seeks its own interest, is strong, the obligatory perception level of CSR will be low. The two traits must exert a negative effect on CSR perception as a prima facie duty, as CSR needs a variety of attention to multi-stakeholders. The non-significant effect of narcissism can be explained as follows. With the viewpoint of positive aspect, it is possible to reinforce the perception of CSR as a prima facie duty for a narcissistic leader who feels self-conscious. On the other hand, a narcissism trait as a strong self-satisfied tendency has a negative effect on the perception of CSR.

The moderating effect of an individual performance-based compensation system was significant in the relationship between Machiavellianism and psychopathy, and prima facie duty. Specifically, the compensation system exacerbated (moderated negatively) the negative relationship between psychopathy and prima facie duty $(\beta=-.137, p<.05)$. The moderating effect was accepted, considering the attribute of psychopathy trait that only concentrates on its own benefits, regardless of others' situation. Hypothesis 2 was supported in this case.

With regard to Machiavellianism, the individual performance-based compensation system improved the negative relationship between Machiavellianism and prima facie duty $(\beta=.125, p<.05)$. The Machiavellianism trait is a goal-directed propensity; therefore, a leader with this trait will regard CSR as a shortcut to personal success and will utilize CSR much more, in order to achieve the individual goal, when a certain compensation system is employed in the manner of direct rewards to individuals. As a normal organization does not accept unethical performance indicators, the leader's perception of 
CSR as a prima facie duty will be strong. No moderating effect was shown for narcissism, as explained above.

Secondly, the main effect was supported partially. The psychopathy trait exerted a negative effect on the perception of CSR as a top priority $(\beta=-.260, p<.05)$. However, Machiavellianism and narcissism had no effect on CSR perception $(\beta=-.154, p>.10$; $\beta=.083, p>.10$ respectively). As mentioned above, the psychopathy trait is cynical, impulsive, selfish, cold and lacking of empathy. Therefore, this empirical result coincides with those reported in the literature. The result for narcissism can be interpreted as an ambilaterality. Machiavellianism is related to a goal rather than a process. According to the specific contents of performance targets-related CSR, a leader with the trait may perceive CSR as a positive or negative issue. The moderating effect did not appear.

\section{Summary and conclusion}

The study has focused on the relationship between a leader's dark triad traits and his or her perception of CSR at the individual level. In particular, the study examined how an individual performance-based compensation system moderates the relationship between dark triad traits and CSR perception. The study results are as follows.

First, when the dependent variable is a prima facie duty, the stronger a leader's Machiavellianism or psychopathy trait, the lower their perception of CSR as a prima facie duty. An individual performance-based compensation system positively moderated the relationship between Machiavellianism and prima facie duty, such that an individual performance-based compensation system improved the negative relationship. On the other hand, the compensation system negatively moderated the relationship between psychopathy and prima facie duty, such that the compensation system exacerbated the negative relationship. Second, when top priority, the stronger a leader's psychopathy trait, the lower his or her perception of CSR as top priority, and no moderating effect was significant.

The negative relationship between Machiavellianism and prima facie duty is attributed to its characteristics of result-orientation and self-centered disposition, or to its ignorance of ethics (Corral and Calvete 2000; Jakobwitz and Egan 2006; Simmons et al. 2009). The positive moderating effect on the negative relationship between Machiavellianism and prima facie duty stems from the possibility that a certain performance evaluation composed of CSR issues related to business (i.e. customer satisfaction, innovation activities, value creation and so on) may impact on the pursuit of personal benefits. Because these issues focus on the tangible outcomes rather than intangible performance like ethical approaches, relationship with stakeholders and social engagements.

The negative relationship between psychopathy and prima facie duty is attributed to the same reason as the negative relationship between Machiavellianism and prima facie duty, because the primary psychopathy is analogous to Machiavellianism (McHoskey et al. 1998). However, the moderating effect on the negative relationship between psychopathy and prima facie duty is negative. First, this is because the most important attribute of psychopathy is a lack of empathy, and thus, the 'individual' rewards will stimulate the attribute. Second, since social responsible activities can appear in the communitarian perspective more easily (Bae et al. 2009), the characteristic of psychopathy cannot help but conflict with communitarianism. The negative relationship between 
psychopathy and top priority can be understood on the basis of the previous studies reported in the literature.

There was no significant result with narcissism. As mentioned above, narcissism is double-sided, as it can have positive or negative influences on business performances and innovations (Rosenthal and Pittinsky 2006; Chatterjee and Hambrick 2007). Similarly, this result between narcissism and CSR may be understood in the same vein. Therefore, if a leader has a narcissistic trait, his or her propensity needs to be promoted positively. Although the market-based approach such as performance evaluation did not work effectively for a narcissistic leader in this research, further research should be conducted to examine the narcissism trait in more detail.

\section{Implications and discussion}

The study results raise two implications. First, this study focused on the negative personality of leaders and their perception on CSR. Previous studies have dealt with the relationship between positive leadership styles and CSR activities or corporate social performance. On the contrary, this study concentrated on the undesirable leader's CSR perception. It is vital to address Machiavellianism, psychopathy, and narcissism in leadership. Management environments have changed rapidly in recent years, and the managerial decision making affects not only the firm but also its society. Therefore, the leader's role and decision making are more crucial. The mass media have covered the business leader's negative behaviors, and can influence organizational leaders interested in becoming "star businessperson." In such a situation, it is even more critical to investigate narcissism trait. In a structured organization, the conflict between the individual's desire and organizational benefits increases, and in a performance-based system, there is a need to pay close attention to Machiavellianism. Moreover, with respect to the proportion of psychopathic CEOs in firms being higher than that of psychopathic individuals in the total population, the attempt to reveal the relationship between the dark triad and CSR perception is important (Boddy et al. 2010).

Considering the results, it is important to deal with the leader's CSR perception in order to activate CSR. The perception of and attitudes to the CSR of a leader in an organization are crucial factors (Bowen 1953; Quazi 2003; Waldman et al. 2006; Waldman and Galvin 2008; Skouloudis and Evangelinos 2012). Given the above discussion, the results have important implications. From a long-term perspective, CSR is relevant to a firm's growth strategy and is closely linked to the sustainable development of society. Therefore, negative aspects of leaders, such as the Dark Triad, should be carefully considered.

Second, the study has empirically investigated the role of an individual performancebased compensation system among a variety of management methods. From the results, an organization needs to know the leader's traits and perception of CSR, and must investigate the performance evaluation system and indicators. An organization also should consider the social, ethical and environmental components as important driver factors. Otherwise, in order to induce ethical behaviors, it is possible to restructure the market-based management system (Bazerman and Tenbrunsel 2011). The study findings reveal the practical need to seek effective managerial approaches capable of controlling the potential propensity desirably, even though it is ethically unfair to give a disadvantage to someone with 'potential' dark triad. The precedent research (Boddy 2011) argued that the 
synergy between experts' negative propensities and the existing rewards systems caused the 2008 financial crisis. Considering this argument, it is imperative to deal with a leader's dark triad, the performance evaluation system and the perception of CSR in the academic field and in various practical sectors.

\section{Further researches and limitations}

The Dirty Dozen scale was used for the dark triad in this study (Jonason and Webster 2010). Though this scale is efficient for conducting a survey, owing to the brief measures, it may be limited in identifying the detail attributes. In particular, Miller et al. (2012) reported that the scale has a limitation in measurement for psychopathy. Further research needs to use other scales in case of complementary, structured and detailed situations.

This study has investigated leaders, including senior-managers, in organizations. It is necessary for future studies to conduct further research on CEOs who can influence the whole organization. Although it is almost impossible to ask CEOs directly about their negative propensity, a peer evaluation should be conducted (Park et al. 2007). Analogously, it is important to reveal the relationship between negative traits and corporate social irresponsibility (CSIR). Finally, if an organization has a complete CSR management strategy and system, the individual performance-based compensation system may play a positive role. Therefore, the various concrete components of the performance evaluation indicators, as well as the intensity of the system, should be examined.

\section{Endnotes}

1"'Rage of the underdogs" erupting in response to Namyang scandal" reported in The Hankyoreh 5/10/2013 (http://www.hani.co.kr/arti/english_edition/e_national/586871.html) or "Dairy scandal reveals food industry's unfair power structure" reported in Yonhapnews Agency 5/7/2013 (http://english.yonhapnews.co.kr/national/2013/05/07/98/0302000000A EN20130507004600315F.HTML)

2"Korean Air nut rage incident prompts South Korea to shell out higher fines" reported in ABC News 1/19/2016 (http://www.abc.net.au/news/2016-01-19/koreanair-nut-rage-incident-prompts-higher-fines-in-south-korea/7098290)

3'Food Rage: Korean Deported Over In-Flight Ramen Brawl" by Jessica reported in Rocket News 24 4/24/2013 (http://en.rocketnews24.com/2013/04/24/food-rage-koreandeported-over-in-flight-ramen-brawl/)

4"Cancer, Death and Samsung's Semiconductor Factories" by John Kay reported in the 3WM 9/2/2012 (http://thethreewisemonkeys.com/2012/09/02/cancer-death-andsamsungs-semiconductor-factories/) or "Report: Samsung endangered workers health in S Korea" reported in Aljazeera 8/10/2016 (http://www.aljazeera.com/news/2016/08/ samsung-endangered-workers-health-south-korea-160810064013370.html)

5"Heads of Samsung and Hyundai Among South Korean Business Leaders Probed Over Presidential Scandal" by Reuters reported in Fortune 12/5/2016 (http://fortune. com/2016/12/05/samsung-hyundai-south-korea-president-scandal/)

"Many on Wall Street Say It Remains Untamed" by Andrew Ross Sorkin reported in New York Times 5/19/2015 (http://www.nytimes.com/2015/05/19/business/dealbook/ many-on-wall-street-say-it-remains-untamed.html?_r =1)

${ }^{7}$ The webpage of KSDC (http://www.ksdc.re.kr/unisql/engjap/ewa/ewa1111.html 


\section{Authors' contributions}

JM carried out the empirical studies and the literature review and drafted the manuscript. YC participated in the design of the study and the statistical analysis, and helped to draft the manuscript. Both authors read and approved the final manuscript.

\section{Competing interests}

The authors declare that they have no competing interests.

Received: 31 March 2016 Accepted: 12 January 2017

Published: 16 February 2017

\section{References}

Ali F, Amorim IS, Chamorro-Premuzic T (2009) Empathy deficits and trait emotional intelligence in psychopathy and Machiavellianism. Personal Individ Differ 47:758-762

Ames DR, Rose P, Anderson CP (2006) The NPI-16 as a short measure of narcissism. J Res Pers 40:440-450

Babiak P, Neumann CS, Hare RD (2010) Corporate psychopathy: talking the walk. Behav Sci Law 28(2):174-193

Bae J, Kim M, Kim Y, Bae J, Oh H (2009) Competing paradigms and research in management: a comparison of liberalism and communitarianism. Korean J Manage 17(2):17-93

Bae J, Park O (2005) Strategic human resource management and organizational innovative performance: a comparative analysis of exploratory versus exploitative innovative performance. Korean J Manage 13(2):147-186

Bagozzi RP, Yi Y (1988) On the evaluation of structural equation models. J Acad Mark Sci 16(1):74-94

Batra MM (2007) The dark side of international business. Competition Forum 5(1):306-314

Bazerman MH, Tenbrunsel AE (2011) Blind spots: Why we fail to do what's right and what to do about it. Princeton University Press, Princeton

Boddy CR, Ladyshewsky RK, Galvin P (2010) The influence of corporate psychopaths on corporate social responsibility and organizational commitment to employees. J Bus Ethics 97(1):1-19

Boddy CR (2011) The corporate psychopaths theory of the global financial crisis. J Bus Ethics 102:255-259

Bowen HR (1953) Social responsibilities of the businessman. Harper, New York

Campbell WK, Brunell AB, Finkel EJ (2006) Narcissism, interpersonal self-regulation, and romantic relationships: An agency model approach. In: Vohs KD, Finkel EJ (eds) Self and relationships: Connecting intrapersonal and interpersonal processes. Guilford Press, New York, pp 57-83.

Chatterjee A, Hambrick DC (2007) It's all about me: Narcissistic Chief Executive Officers and their Effects on Company Strategy and Performance. Adm Sci Q 52:351-386

Collins MA, Amabile TM (1999) Motivation and creativity. In: Sternberg RJ (ed) Handbook of creativity. Cambridge University Press, Cambridge, pp 297-312

Converse JM, Presser S (1986) Survey questions: Handcrafting the standardized questionnaire. In: Sage University Paper: Quantitative Applications in the Social Sciences, vol 63. Sage, Thousand Oaks

Corral S, Calvete E (2000) Machiavellianism: dimensionality of the Mach IV and its relation to self monitoring in a Spanish sample. Span J Psychol 3(1):3-13

Deci EL (1971) Effects of externally mediated rewards on intrinsic motivation. J Pers Soc Psychol 18(1):105-115

Deci EL, Koestner R, Ryan RM (1999) A meta-analytic review of experiments examining the effects of extrinsic rewards on intrinsic motivation. Psychol Bull 125(6):627-668

Eisenberger R, Armeli S (1997) Can salient reward increase creative performance without reducing intrinsic creative interest? J Pers Soc Psychol 72(3):652-663

Emmons RA (1987) Narcissism: theory and measurement. J Pers Soc Psychol 52(1):11-17

Etheredge JM (1999) The perceived role of ethics and social responsibility: An alternative scale structure. J Bus Ethics 18(1):51-64

Farwell L, Wohlwend-Lloyd R (1998) Narcissistic processes: optimistic expectations, favorable self-evaluations, and self-enhancing attributions. J Pers 66(1):65-83

Ford RC, Richardson WD (1994) Ethical decision making: a review of the empirical literature. J Bus Ethics 13(3):205-221

Fox J (2000) Approaching managerial ethical standards in Croatia's hotel industry. Int J Contemp Hosp Manag 12(1):70-74

Furtner MR, Rauthmann JF, Sachse P (2011) The self-loving self-leader: an examination of the relationship between self-leadership and the dark triad. Soc Behav Pers 39(3):369-379

Geis F, Moon T (1981) Machiavellianism and deception. J Pers Soc Psychol 41:766-775

Heneman RL (1992) Merit pay: linking pay increases to performance ratings. Addison-Wesley Publishing Co., New York Hogan R, Raskin R, Fazzini D (1990) The dark side of charisma. In: Oark KE, Clark MB (eds) Measures of leadership. Leadership Library of America, West Orange, pp 343-354

Jakobwitz S, Egan V (2006) The dark triad and normal personality traits. Personal Individ Differ 40:331-339

Jonason PK, Webster GD (2010) The dirty dozen: a concise measure of the dark triad. Psychol Assess 22(2):420-432

Judge TA, LePine JA, Rich BL (2006) Loving yourself abundantly: relationship of the narcissistic personality to selfand other perceptions of workplace deviance, leadership, and task and contextual performance. J Appl Psychol 91:763-776

Karpman B (1948) The myth of the psychopathic personality. Am J Psychiatr 104:523-534

Kim K, Kim S (2006) High-performance HRM and organizational performance: an exploratory study on the role of the Intensiveness of HRM system. Korean J Manage 14(3):107-151

Kim Y, Jun S, Yi P (2008) Reliability and validity of the Korean version of the social desirability scale-17. Korean J Soc Welf Stud 38:5-32

Klann G (2003) Character study: strengthening the heart of good leadership. Leadersh Action 23(3):3-7

Kowalski RM (2001) Behaving badly: aversive behaviors in interpersonal relationships. American Psychological Association, Washington 
Lee K, Ashton MC (2005) Psychopathy, Machiavellianism, and Narcissism in the five-factor model and the HEXACO model of personality structure. Personal Individ Differ 38:1571-1582

Levenson MR, Kiehl KA, Fitzpatrick CM (1995) Assessing psychopathic attributes in a noninstitutionalized population. J Pers Soc Psychol 68:151-158

Marrewijk MV, Werre M (2003) Multiple levels of corporate sustainability. J Bus Ethics 44(2):107-119

McHoskey JC, Worzel W, Szyarto C (1998) Machiavellianism and psychopathy. J Pers Soc Psychol 74(1):192-210

Milkovich GT, Newman JM (1996) Compensation. Irwin, Chicago

Miller JD, Few LR, Seibert LA, Watts A, Zeichner A (2012) An examination of the dirty dozen measure of psychopathy: a cautionary tale about the costs of brief measures. Am Psycholog Assess 24(4):1048-1054

Morf CC, Rhodewalt F (2001) Unraveling the paradoxes of narcissism: a dynamic self-regulatory processing model. Psychol Inq 12:177-196

Nathanson C, Paulhus DL, Williams KM (2004) The challenge to cumulative learning: do introductory courses actually benefit advanced students?". Teach Psychol 31(1):5-9

Park S (2007) A study on the dilemmas of performance-based HRM system: based on a case analysis of Fujitsu's HRM system. Korean J Manage 15(1):135-174

Park W, Kim M, Jung S, Heo G (2007) Causes and remedies of common method bias. Korean J Manage 15(1):89-133

Paulhus DL, Hemphill JE, Hare RD (2006) Scoring manual for the hare self-report psychopathy scale-III. Multi-Health Systems, Toronto

Paulhus DL, Williams KM (2002) The dark triad of personality: Narcissism, Machiavellianism, and psychopathy. J Res Pers 36(6):556-563

Peng GZ (2008) The effect of national corporate responsibility environment on Japanese MNCs' location choice. In: Academy of Management Proceedings., pp 1-6

Perrini F (2006) Corporate social responsibility: doing the most good for your company and your cause. Acad Manag Perspect 20(2):90-93

Promislo MD, Giacalone RA, Welch J (2012) Consequences of concern: ethics, social responsibility, and well-being. Bus Ethics A Eur Rev 21:209-219

Quazi AM (2003) Identifying the determinants of corporate managers' perceived social obligations. Manag Decis 41(9):822-831

Raskin RN, Hall CS (1981) The narcissistic personality inventory: alternative form reliability and further evidence of construct validity. J Pers Assess 45:159-16

Robbins F (2008) Why corporate social responsibility should be popularised but not imposed. Corp Gov 8(3):330-341

Robins RW, John OP (1994) Effects of visual perspective and narcissism on self perception: is seeing believing? Psychol Sci 8(1):37-42

Rosenthal SA, Pittinsky TL (2006) Narsissistic leadership. Leadersh Q 17:617-633

Sedikides C, Campbell WK, Reeder G, Elliot AJ, Gregg A (2002) The self in relationships: whether, how, and when close others put the self in its place. Eur Rev Soc Psychol 12:237-265

Simmons R, Shafer W, Snell R (2009) Effects of a business ethics elective on Hong Kong undergraduates' attitudes toward corporate ethics and social responsibility. Bus Soc 52(4):558-591

Singhapakdi A, Vitell SJ (1991) Analyzing the ethical decision making of sales professionals. J Pers Sell Sales Manag 11(4):1-12

Singhapakdi A, Vitell SJ, Rallapalli KC, Kraft KL (1996) The perceived role of ethics and social responsibility: a scale development. J Bus Ethics 15:1131-1140

Skouloudis A, Evangelinos K (2012) Corporate social responsibility in Greece: Current developments and future prospects, in Greece. In: Liargovas P (ed) Economics, political and social issues. Nova Publishers, New York

Stöber J (2001) The social desirability scale-17(SDS-17): Convergent validity, discriminant validity, and relationship with age. Eur J Psychol Assess 17(3):222-232

Swanson DL (2006) Corporation, be good! The story of corporate social responsibility. Acad Manag Learn Educ 5(3):379-382

Thomas AS, Simerly RL (1994) The chief executive officer and corporate social performance: An Interdisciplinary Examination. J Bus Ethics 13(12):959-968

Valentine S, Fleischman G (2008) Professional ethical standards, corporate social responsibility, and the perceived role of ethics and social responsibility. J Bus Ethics 82(3):657-666

Vitell SJ, Paolillo JG (2004) A cross-cultural study of the antecedents of the perceived role of ethics and socia responsibility. Bus Ethics A Eur Rev 13:185-199

Waldman DA, Galvin BM (2008) Alternative perspectives of responsible leadership. Organ Dyn 37:327-341

Waldman DA, Siegel DS, Javidan M (2006) Components of CEO transformational leadership and corporate social responsibility. J Manag Stud 43(8):1703-1725

Wallace HM, Baumeister RF (2002) The performance of narcissists rises and falls with perceived opportunity for glory. J Pers Soc Psychol 82:819-834

William BW, David BC (2011) Strategic corporate social responsibility: Stakeholders in a global environment. SAGE Publications, Thousand Oaks

Williams K, Nathanson C, Paulhus D (2002) Factor structure of the self-report psychopathy scale: Two and three factor solutions. Paper presented at the annual meeting of the Canadian Psychological Association, Vancouver

Yu G, Park W (2007) Determinants and Organizational effectiveness of performance-based human resource management. Korean J Manage 15(3):187-224 